\title{
1848.
}

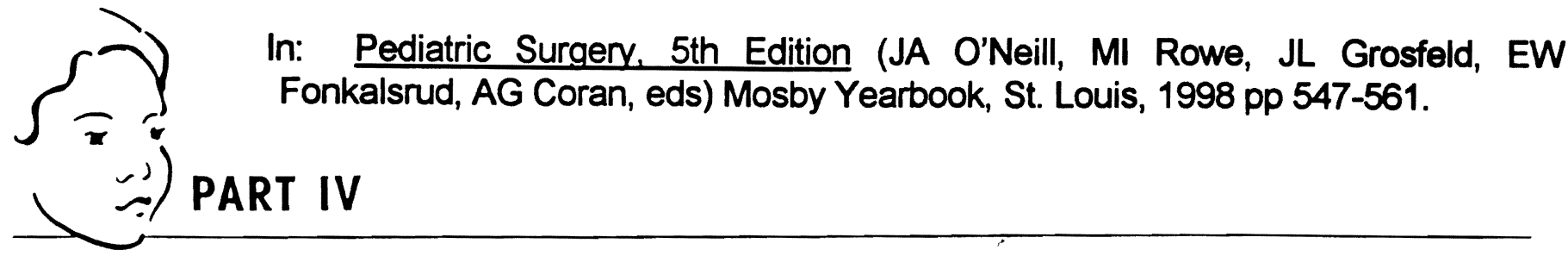

TRANSPLANTATION

\section{Principles of Transplantation}

\author{
Jorge Reyes, Thomas E. Starzl
}

Assuming the availability of a good intensive care unit and effective outpatient care, successful transplantation of any whole organ rests on five specific laboratory-based principles: surgical technique; preservation technology; considerations of histocompatibility; immunosuppression; and, least appreciated, the incidental induction of varying degrees of donor-specific nonreactivity (tolerance), without which none of our organ recipients could be rehabilitated for long. Traditionally, the last three of these considerations have been discussed separately. However, the discovery in 1992 that all patients bearing long surviving organ allografts had donor leukocyte chimerism ${ }^{80.81}$ and the realization that this must be accomplished for successful xenotransplantation $^{96}$ has made such a reductionist approach obsolece. Consequently, the first section of this chapter will describe the interrelation of histocompatibility, immunosuppression, and tolerance. The last two sections will briefly discuss organ preservation and the limitations of clinical tissue matching. Expositions of surgical technique can be found in organ-specific chapters.

\section{THE IMMUNOLOGIC BARRIER}

The modern evolution of clinical transplantation of whole organs has spanned 40 years. This evolution has involved some of the most remarkable and conceptually enigmatic developments in the history of medicine. Successful engraftment of the kidney, ${ }^{50}$ liver, ${ }^{84}$ heart, ${ }^{9}$ lung, ${ }^{23}$ pancreas, ${ }^{36}$ intestine, ${ }^{31}$ and multiple abdominal viscera ${ }^{94}$ was a cumulative achievement, largely accomplished by dogged trial and error. Each organ-defined specialty has had historians who track their story back to one of the foregoing milestones where the trail goes cold. The reason is that such accounts are preoccupied with a succession of events rather than the biologic principles that apply to all organ allo-

Aided by Research Grants from the Veterans Administration and l'roject Cirant No 1)K29\%621 from the National Institutes of Health. Berhesda. Maryland. grafts. This was understandable because there was no rational reason to expect that a transplanted histoincompatible organ could breach the seemingly inviolate barrier of immunologic reactivity using the treatment formulas that became standard. When this proved feasible, the inability to explain why caused an ever-increasing number of clinical transplant surgeons and physicians to regard basic immunology as an interesting hobby, irrelevant to their practice.

\section{The Beguiling Identical Twins}

The potential benefit of whole organ replacement in the absence of an immune barrier was dramatically demonstrated with the identical twin kidney transplantation performed in December 1954 by Murray ${ }^{49}$ (Nobel Laureate, 1990). Although symbolically important, this achievement only confirmed what already was known to be possible with identical twin skin grafts. ${ }^{49}$ Seven years later, the Nobel Laureate (1960), Burnet ${ }^{16}$ reported in The New England Journal of Medicine that " . . much thought has been given to ways by which tissues or organs not generically and antigenetically identical with the patient might be made to survive and function in the alien environment. On the whole, the present outlook is highly unfavorable to success. ..."

\section{The One-Way Paradigm}

\section{Rejection}

What was the genetically determined barrier? Although it has never been precisely defined, there was little mystery after 1944 about the general meaning of rejection after its elucidation by Medawar $^{46}$ (co-Nobel Laureace with Burnet, 1960) as an immunologic event. This great contribution created the indelible image that a tissue (or organ) allograft was an island in a hostile recipient sea (Fig. 35-1, A).

\section{Tolerance}

In contrast, why allografts or xenografts could escape from rejection without crippling the recipient with immunosuppression 

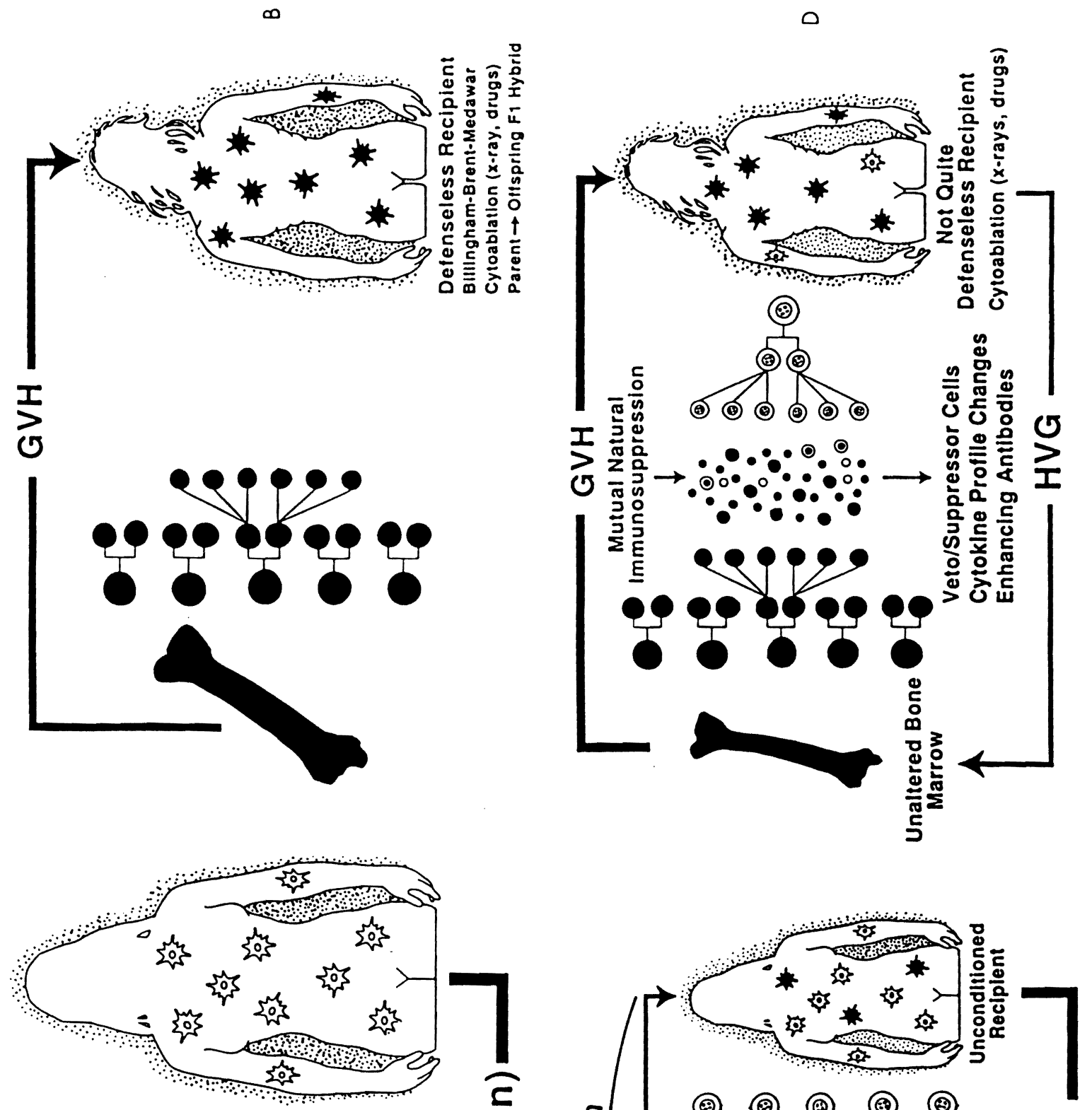

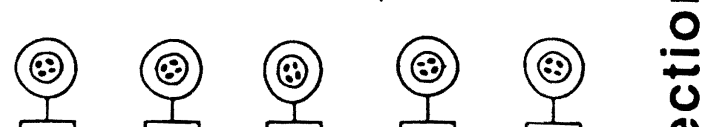

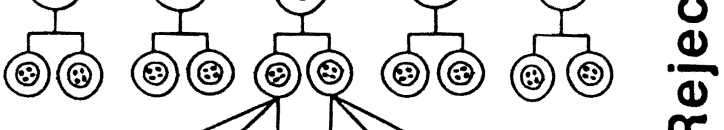
(ㄱ) (3) (3) (3) (9) (3)

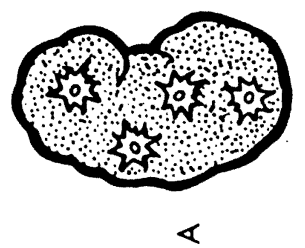
㽞

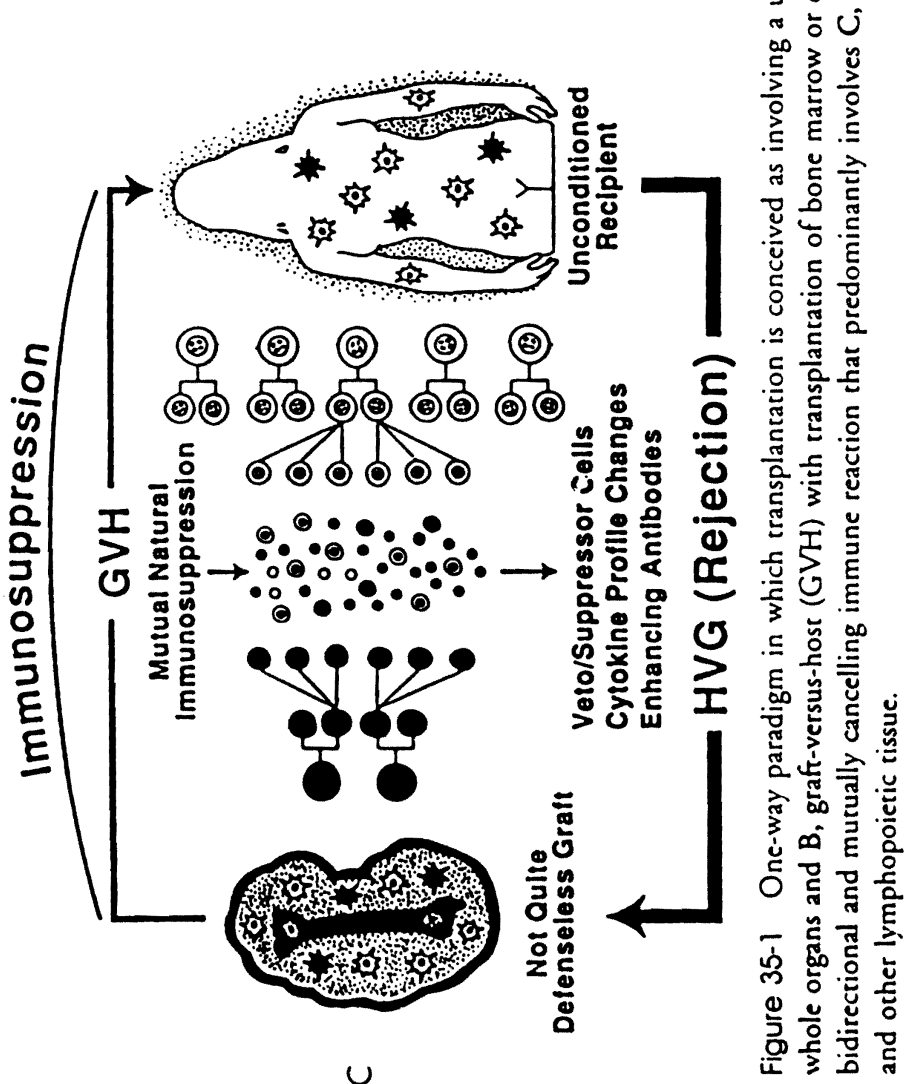


was one of the great mysteries of biology for ncarly 40 years afecr the description of acquired tolerance by Billingham et al. ${ }^{13.14}$ In their experimental model, immunocompetent adult splecen cells were injected in utero or perinatally into mice that were not yet immunologically able to reject them. The engrafted cells flourished and in effect endowed the recipient with the donor immune system (leukocyte chimerism) (Fig. 35-1, B).

Thereafter, the mice failed to recognize donor strain skin grafts or other tissues as alien (a concept known as acquired tolerance). The switch in immunologic apparatus was consistent with the definition of transplantation immunology in terms of a unidirectional immune reaction (the "one-way paradigm"). Main and Prehn "1" demonstrated the same tolerance outcome as Billingham et al ${ }^{13.14}$ in irradiated adult mice, whose cytoablated hematolymphopoietic cells were reconstituted with bone marrow instead of spleen cells. Hundreds of subsequent tolerance induction experiments in animals and eventually clinical bone marrow transplantation seemingly depended upon a similar natural, or iatrogenically imposed, defenseless recipient state (see Fig. 35-1, B).

\section{Graft-versus-host disease}

It was recognized as early as 1957 in mouse ${ }^{12}$ and chicken mod$\mathrm{els}^{70}$ that an immunologically active graft could turn the tables and reject the recipient, using a complete genetically controlled repertoire of immune reactivity similar to that of the recipient. This was called graft-versus-host disease (GVHD), or alternatively "runt disease". If the host was immunologically defenseless, the risk for this disease was approximately proportional to the extent of the major histocomparibility complex (MHC) difference between donor and recipient. Such disparities became measurable serologically in humans after identification of the HLA antigens by Dausser ${ }^{21}$ (Nobel Laureate, 1980), Terasaki, ${ }^{101}$ and orhers whose reminiscences have recently been collected. For many years, the complication of GVHD in rodent ${ }^{110}$ and large animal irradiation chimera models $s^{34.41 .60 .105}$ forestalled the clinical use of HLA-mismatched bone marrow cells or other mature immunocytes both for immunologic reconstitution with purely hematologic objectives and as a means of facilitating whole organ graft acceptance.

\section{Clinical bone marrow transplantation}

The strategy that eventually made possible clinical bone marrow transplantation in 1968 was a straightforward extension of the rodent experiments with similar histocompatibility-inposed restrictions. ${ }^{5.29 .44}$ After recipient cytoablation with total body irradiation or cytotoxic drugs (see Fig. 35-1, B), stable chimerism could be induced in humans by the infusion of donor bone marrow if there was a good HLA match. Otherwise, an incolerable incidence of lethal GVHD occurred. At varying times afrer successful engraftment, maintenance immunosuppression was trequently nor needed, mimicking the kind of acquired inmunologic colerance originally described by Billingham er a $\left.\right|^{13.14}$ and then Main and Prehn."

\section{Clinical organ transplantation}

Total body irradiation

The accomplishment of clinical bone marrow transplantation effectively detached from a scientific base surgeons and physicians who by this cime had recorded many successful human whole organ transplantations (mostly kidncys) under continuous immunosuppression without cither dependence on HI.A matching or the complication of (;VHD. Most immunologists were dumbfounded by these successes.

Host preconditioning played a historically important role in the first six successful renal transplantations (defined as survival for more than 1 year) between 1959 and 1962 -one in Boston ${ }^{50}$ and five in France. ${ }^{32.38}$ The recipicnts were prepared for operation with sublethal total body irradiation but without donor bone marrow. Theit uwn bone marrow recovered, and one of these patients (in Paris) survived for 26 years; however, these were isolated successes in a sea of failures, and pessimism set in worldwide about the prospects of moving forward.

\section{Chemical immunosuppression}

The frustration continued after the introduction for human renal transplantation of 6-mercaptopurine (6-MP) and its analogue, azathioprine, following extensive experimental studies, first with rodent skin transplantation ${ }^{47.68}$ and then with canine kidney transplant models. ${ }^{17.18 .53 .118}$ The drugs were originally developed as antileukemic agents by Elion and Hitchings ${ }^{25}$ (Nobel Laureates, 1988) and were first demonstrated to be immunosuppressive by Schwartz and Dameshek. ${ }^{67}$ Although the sixch patient treared by Murray with one or the other of these myelotoxic drugs had function in a non-related renal allograft for 17 months, the clinical results were poor at first, ${ }^{53.54}$ similar to those with total-body irradiation (TBI).

\section{The drug cocktail breakthrough}

When azathioprine was combined with prednisone in $1962-63,{ }^{30}$ the tidal wave of whole organ cases began in earnest. A characteristic cycle of convalescence was identified in which kidney rejection could be reversed surprisingly easily with prednisone. More important, the later need for maintenance immunosuppression frequently declined as if the immune barrier had been lowered (Fig. 35-2); and in occasional cases therapy could be stopped. The same sequence has been seen since with all ocher organs transplanted and with all of the two-drug and more complex nulkiple agent immunosuppressive regimens. Drugs introduced later were more potent and reliable in chaperoning the desired chain of events: antilymphocyte globulin (ALG)." cyclosporine." and FK 506."s Notwithstanding their diversity, all seened in a fundamentally similar way to have allowed something to change in the host, the graft or both. But what?

Answers were not provided by the one-way paradigm. Nevertheless, the false conception of a unidirectional reaction was reinforced with the incroduction in 1963 of the one-w:yy mixed lymphocyre reaction. ${ }^{4.7}$ These and other in vitro rechniques (the so-called minitransplant models) generated thousinds 
Figure 35-2 Partern of postoperarive events with whole organ allograft acceptance in the framework of the one-ivay paradigm.

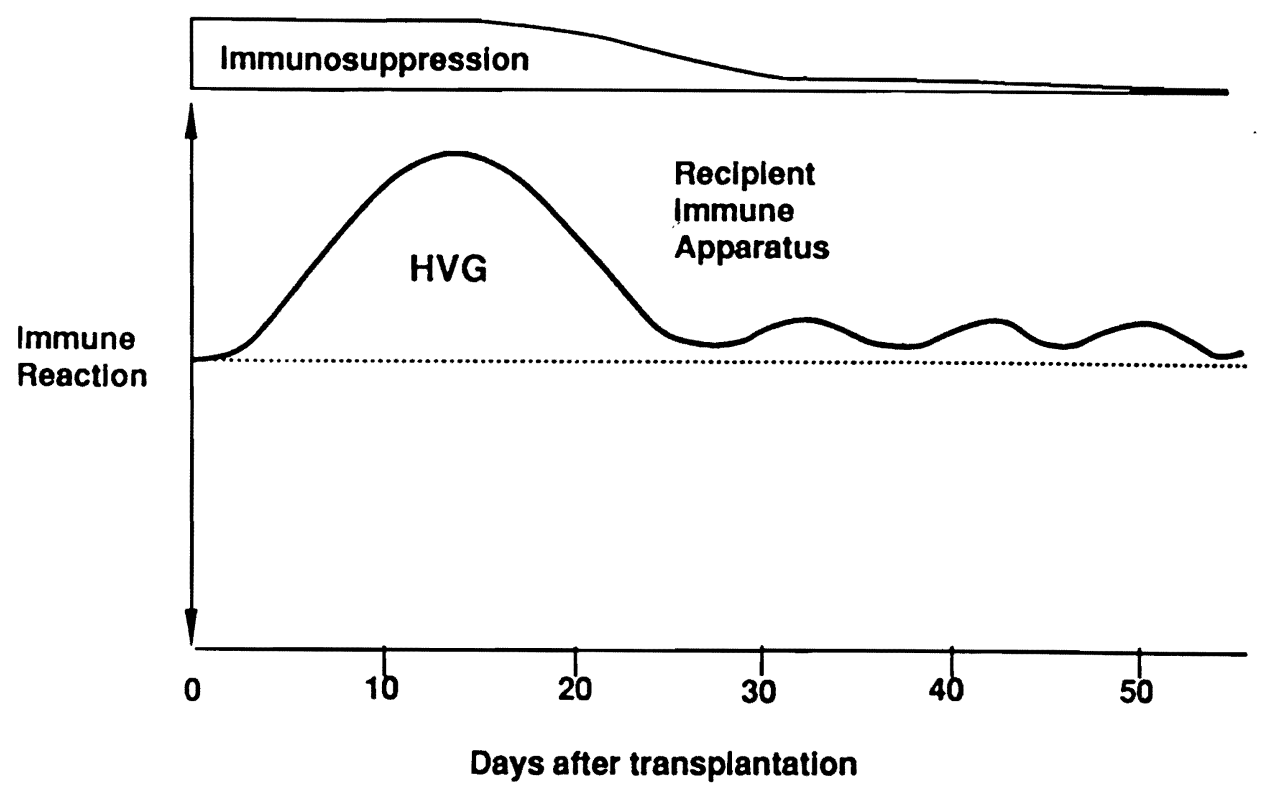

of increasingly sophisticated cellular and ultimately molecular studies of unidirectional immunologic reactions. The resulting plethora of new information resembled at times the entries in an exponentially expanding phone book. Most seriously, the flawed context lured successive generations of investigators into the trap of believing that colerance induction for whole organ recipients (the "holy grail") lay in variations on the HLA-limiting strategy that was used for bone marrow transplantation. This strategy included host preconditioning in preparation for various donor leukocyte preparations.

\section{Cell-mediated immunity}

By the early 1970s, most virologists and basic immunologists who were attempting to understand organ rejection shifted their efforts from whole animal studies to the T lymphocyte-oriented cell culture (i.e., in vitro) systems. These labors were rewarded by a Nobel Prize (Baruj Benacerraf, 1980) and the Lasker Prize in Basic Science of 1995, which was shared by four Americans and one Swiss. 21.112 .117 The conceptual model that emerged from these studies provided an explanation of cell-mediated immunity (Fig. 35-3). In the context of the one-way paradigm, the details of the allogeneic reaction (i.c., rejection) included its dependence on antigen-presenting cells, the necessity for a costimulatory molecule(s) (the two-signal concept of self/nonself-discrimination), the important role of accessory molecules, and cytokine control of clonal expansion of T-helper lymphocytes as well as of the cytotoxic T cells that are the agents of allograft destruction. The bewildering mass of details to which thousands of investigators had contributed over a 3 -decade period had long since overwhelmed most clinicians interested in applying the new information.

In the meanwhile, the surprising diversity had been documented of agenes with which long-term or permanent graft survival could be induced with a short course of therapy, regardless of the level at which the agent incervenes in the immune reaction" 1 (1:ig. 35-3). 1)eoxyspergualin was believed to alter the function of antigen-presenting cells, of which dendritic cells were considered to be the most important. The antimetabolite drugs prevented clonal expansion of lymphocytes by inhibition of deoxyribonucleic acid (DNA) synthesis. Cyclosporine and tacrolimus (FK 506) disrupted signals from $T$-cell receptor sires to the nucleus. Monoclonal antibodies (MA) interrupted the immune reaction at the various specific targets shown in Figure 35-3, and rapamycin interdicted the sequence of events even after the secretion of the cytokine interleukin 2 (formerly called $\mathrm{T}$-cell growth factor). The new immunosuppressive fusion protein CTLA4-Ig blocks the transmission of a second signal (the B7-CD28 pathway). All appeared to be permissive of a natural event that became specific only by virtue of the presence of donor antigens.

\section{The Two-Way Paradigm}

\section{Whole organ transplantation}

Insight into what was happening to the pioneer organ recipients was obtained in retrospect by studies at the University of Pittsburgh nearly 30 years later of a group of kidney and liver recipients who were still extant from the earliest clinical trials at the University of Colorado. Donor leukocytes of bone marrow origin ("passenger leukocytes"71.\%"), which are part of the structure of all complex grafts, were found to have migrated from the organs and survived ubiquitously in the patients for up to 3 decades. ${ }^{80.81}$ Thus, organ allograft acceptance was associated with the cryptic persistence of a small fragment of extramedullary donor marrow, including stem cells (depicted as a bone silhouete in Fig. 35-1, C). These cells had been assimilated into the overwhelmingly larger immunologic network of the host. The leukocyte movement occurred in both directions, with a small number of residual donor leukocytes (microchimerism) in both the graft and host.

From this information, a revision of transplantation immunology was possible in which the immunologic confrontaion following whole organ transplantation could be seen as a 


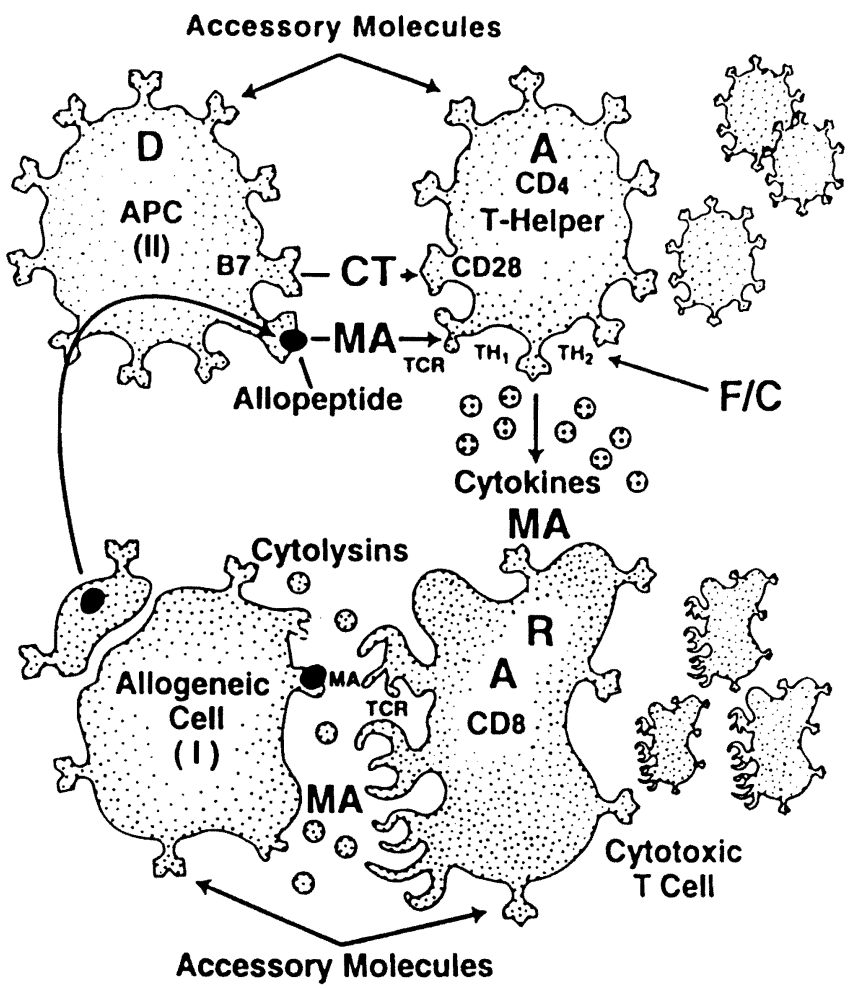

Figure 35-3 A schematic representation of the antiallograft immune response showing the cell-surface proteins that participate in antigen recognition and signal transduction, the contribution of cytokines, and the sites of action of the diverse agents that prolong graft survival. Antigen (allopepride) recognition by means of the $\mathrm{T}$-cell receptor (TCR) and the role of accessory molecules can be blocked by monoclonal antibodies (MA), as can cyrokine-receptor expression. Deoxyspergualin (D) is believed to inhibit the function of antigen-presenting cells (APC). FK 506 (F) (now tacrolimus) and cyclosporine $(C)$ inhibit cytokine gene expression within $T$-helper (TH) cells, whereas rapamycin (R) blocks the responses of $T$ cells to interleukin (IL)2. By inhibiting DNA synthesis, the antimetabolite drugs (A) act later than FK 506, cyclosporine, or rapamycin to block lymphocyte proliferation. CTLA4- $\operatorname{Ig}(C T)$ is a new agent that blocks transmission of the second signal (B7-CD28) pathway that is essential for T-cell activation. (I) and (II): major histocompatibility complex (MHC) antigens class I and II, respectively.

bidirectional and mutually cancelling (graft-versus-host [GVH] as well as host-versus-graft [HVG]) interaction (Fig. 35-4), providing the two participants in the David/Goliath mismatch could survive the initial confrontation. Clinically, but not in several animal models, such survival requires an umbrella of immunosuppression that protects both cell populations equally (see Fig. 35-1, C).

Understanding the amplication device by which a small number of donar cells can so profoundly affect the immunologic vision of the vast recipient army against which it is arrayed is of intense scientific interest. The chimeric leukocytes are multilineage. ${ }^{22.58 .80 .81}$ However, the antigen-presenting dendritic cells (DCs) of Steinman and Cohn ${ }^{97.98}$ are believed to be key to the reciprocal tolerogenic process because they can modify, in both cell populations, the expression of cell interaction. MHC, and adhesion molecules-all of which determine how antigen signals are hecded by T" cells."

\section{Historical enigmas}

With the two-way paradigm, the reason for virtually every previously unexplained experimental or clinical observation after whole organ transplantation became either transparent, or at least susceptible to experimental inquiry. ${ }^{80,81}$ It could be understood why organ grafts are inherently tolerogenic, why HLA matching is so poorly predictive of outcome, and why GVHD does not develop after the transplantation of immunologically active grafts (such as the liver and intestine) or as it was soon learned, even of bone marrow providing the recipient immunologic system is left intact.

With the two-way mutual cancellation implicit in this concept, the loss or blunting of an HLA-matching effect is easy to understand. With each further level of histoincompatibility, the reciprocal effect apparently escalates both ways under the umbrella of effective immunosuppression (Fig. 35-5). The consequent dwindling of the matching effect as donor-specific and recipient-specific nonreactivity evolves accounts for "blindfolding" of the expected HLA influence.

In addition to explaining why the HLA matching effect is mitigated, the mutual functional cancellation of the two cell populations explains why GVHD does not develop after liver, intestinal, multivisceral, and heart-lung transplantation, despite the heavy lymphoid content of those organs.

\section{Augmentation of spontaneous chimerism}

Because acquisition of immunologic tolerance in the BillinghamBrent-Medawar and derivative models depended on donor leukocyte (splenocyte or bone marrow) infusion, ${ }^{13.14 .40}$ sporadic attempts have been made to improve organ allograft outcome by infusing adjuvant donor bone marrow ${ }^{8.51}$ or blood. ${ }^{3.64 .72}$ These were hampered in design or execution by the assumption that the infused cells would be destroyed unless there were recipient preconditioning with irradiation or myelotoxic drugs. In turn, the prospect of recipient cytoablation engendered justifiable anxiety about causing GVHD. The appropriate timing of the cell infusions was also controversial. Consequently, this strategy never gained a clinical foothold.

The information that emerged in 1992 indicating that leukocyte chimerism is a naturally occurring event after whole organ transplantation ${ }^{80.81}$ exposed a perioperative window of opportunity during which unaltered HLA-incompatible bone marrow or donor-specific blood transfusion were predicted to be safe without recipient preparation or any deviation from the generic noncytoablative practices of inmunosuppression for whole organ transplantation that had evolved over the years from the original prednisone/azathioprine formula. ${ }^{90}$

The validity of this strategy was verified recently in nonpreconditioned recipients of cadaveric kidneys, livers, hearts, and lungs who were given 3 to $5 \times 10^{\mathrm{x}} / \mathrm{kg}$ adjuvant bone marrow cells during organ transplantation under standard tacrolinusprednisone treatment (Fig. 35-6). ${ }^{28}$ Chinerism estimated to be more than 1000 times that which occurs in conventional whole 
Figure 35-4 The pattern of convalescence after either organ or bone marrow transplantation in the framework of the two-way paradigm.

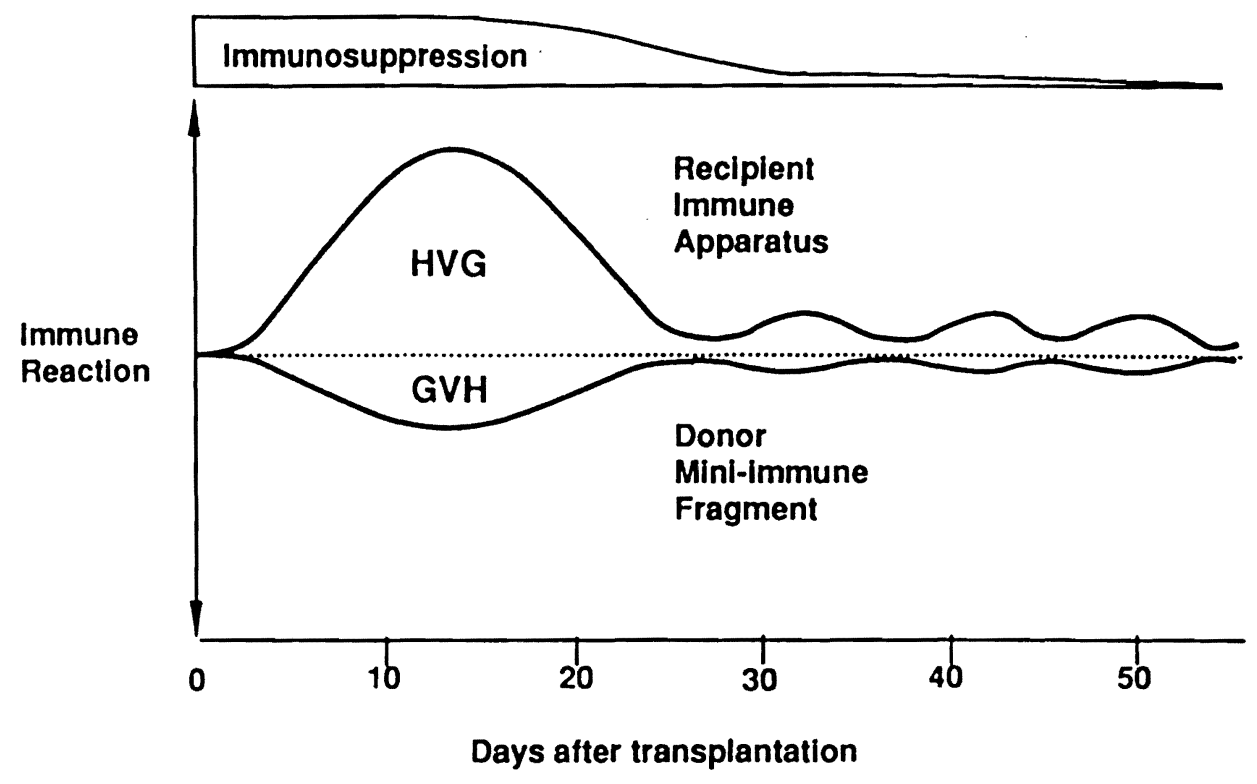

Figure 35-5 Explanation for the loss of an HLA-matching effect with whole organ transplantation. Rx-Immunosuppression.

Partial Mismatch
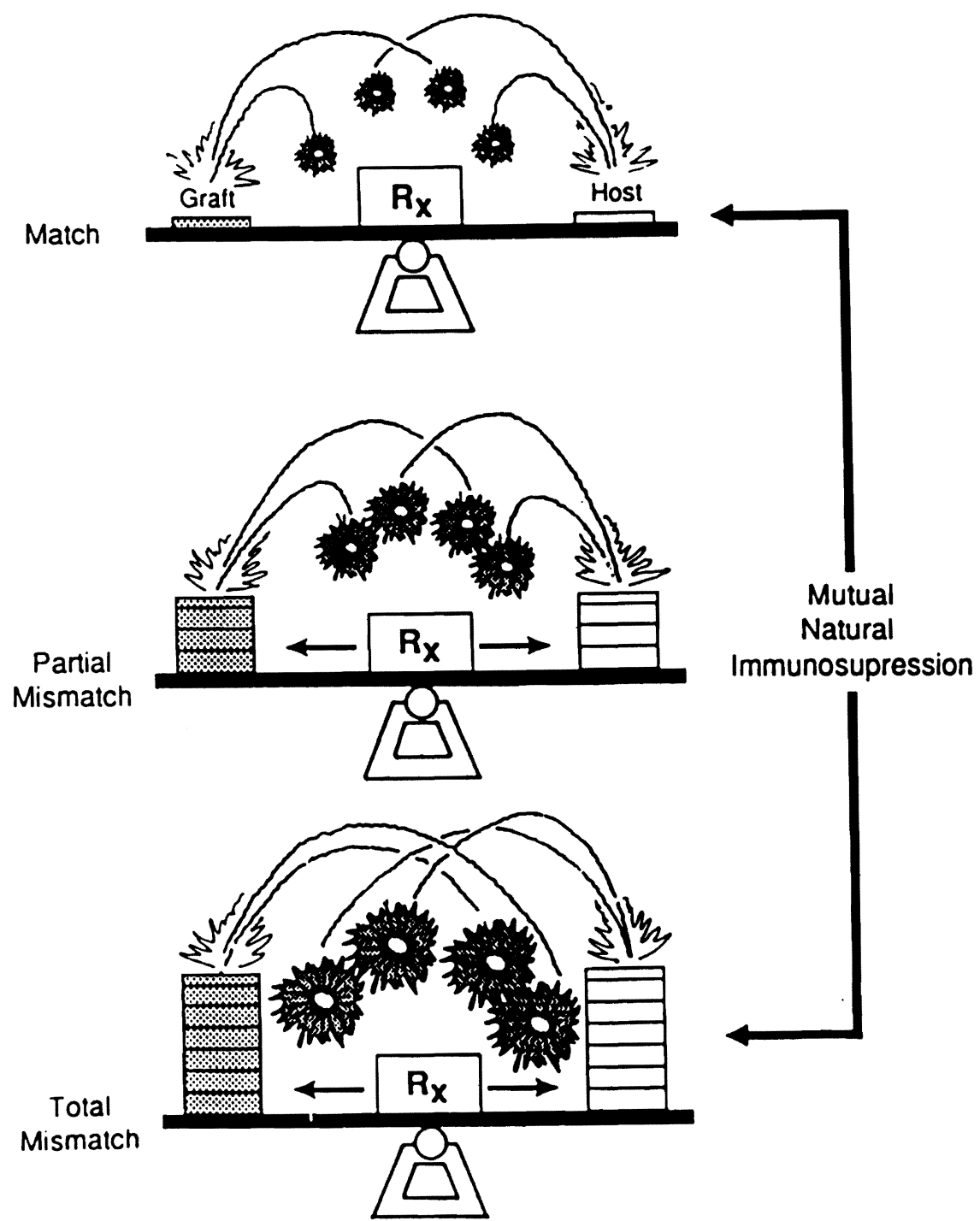


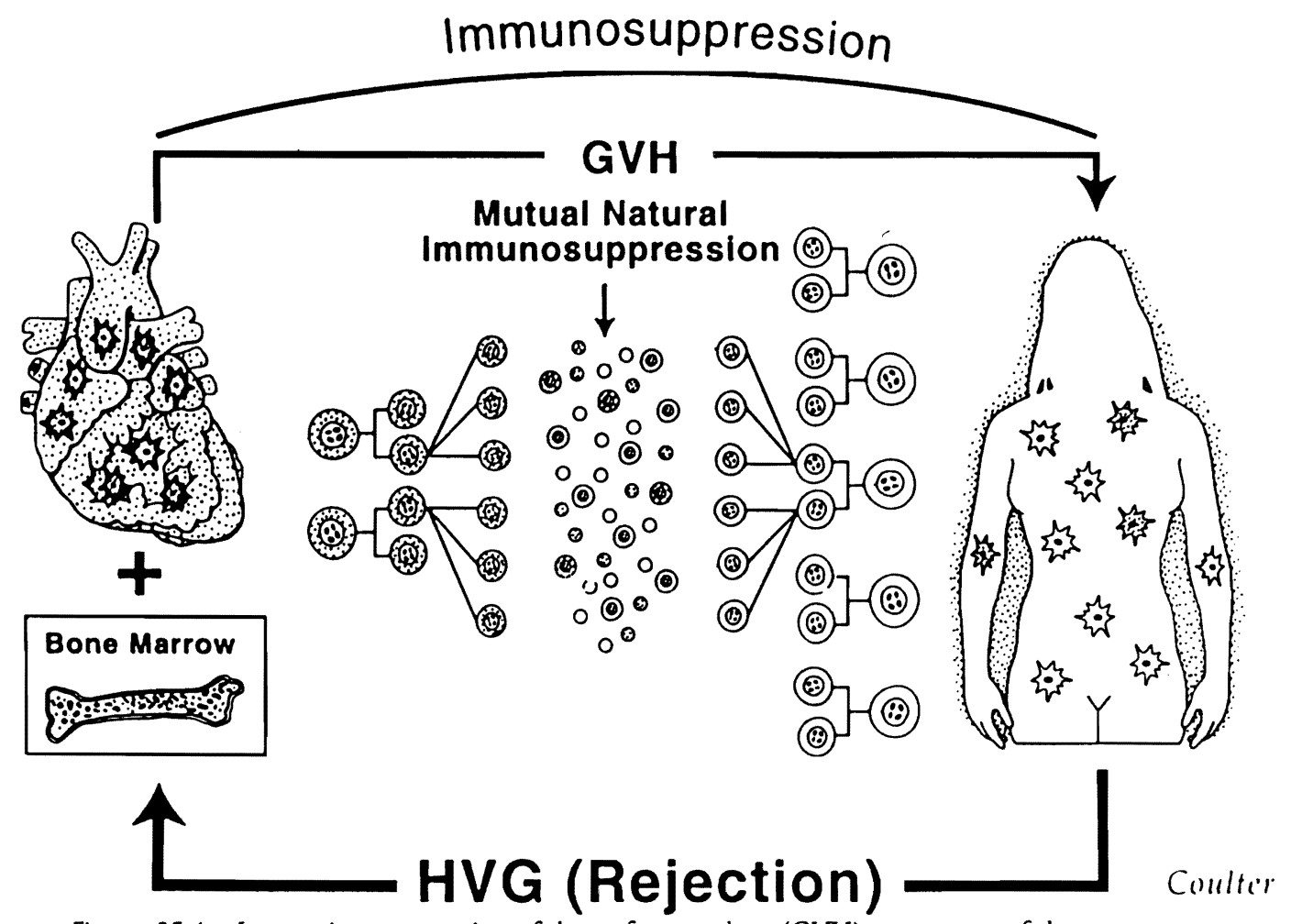

Figure 35-6 Iatrogenic augmentation of the graft-versus-host (GVH) component of the two-way paradigm by infusing 3 to $6 \times 10^{8}$ unaltered donor bone marrow cells during whole organ transplantation. When the recipient is not cytoablated, essentially no risk for GVH disease exists.

organ recipients was produced and sustained reliably and safely. The persistent blood chimerism (usually $>1 \%$ ), trend toward donor specific nonreactivity, and high rate of patient and graft survival has marked these bone marrow-augmented recipients as an advantaged cohort. These patients are the first to undergo HLA-mismatched cadaveric organ transplantation with the hope of eventually becoming drug free. The process of tolerance induction and drug weaning is expected to take 5 to 10 years; and, in some the drug free state may never be attainable.

\section{The drug-free state}

The concept that organ transplantation is equivalent to a small bone marrow transplantation (and that this explains allograft acceptance) has gone well beyond a hypothesis. The human phenomenology has been confirmed and greatly extended in animal models, principally by Qian et al, ${ }^{58}$ Murase et al,, 52 and Demetris et al. ${ }^{22}$ The cardinal principle revealed by the clinical and animal studies is that the long and continuing survival of an organ allograft means by definition that donor leukocyte chimerism is present. Failure to demonstrate chimerism in such recipients connotes an inadequate search. ${ }^{52}$

Does this mean that chimerism is synonymous with tolerance? Of course not. Donor leukocyte chimerism is merely a prerequisite for graft acceptance. ${ }^{80}$ Is the demonstration of chimerism an indication to stop immunosuppression? This shockingly naive question has been asked of us dozens of times, even by experienced clinicians. The answer is "No"! However, knowledge of the chimerism mechanism makes it clear why drugs can be stopped permanently after organ transplantation in some cases.

In early 1992, we formally reevaluated 43 liver recipients who had received the transplant 10 to 23 years previously. ${ }^{81}$ More than half of the recipients had been infants or children at the time of their operation. Five (12\%) of the 43 were already off drugs at that time, and had been for 1 to 15 years. Since then, one of the 43 long survivors died from recurrent hepatitis $B$, leaving 42 survivors in October 1995. During the 3.5 intervening years, seven more of these recipients came off of drugs. Thus, the incidence of drug freedom in this bellwether cohort of liver recipients, who represent approximately $80 \%$ of the longest survivors in the world after this procedure, is 12 of 42 or $28 \%$. The nearly equal cumulative duration of these $12 \mathrm{pa}$ tients off of immunosuppression (coded grey) and under treatment (shown in black) is evident in Figure 35-7.

Complementing the foregoing observations, Ramos et al ${ }^{59}$ have reported a prospective weaning trial for liver recipients, limited for the most part to patients who were 5 to 10 years post-transplantation. Freedom from rejection for at least 5 years was a prerequisite. Since the first report, the trial has expanded to 80 patients (Fig. 35-8). Forty-four (55\%) of these liver recipients have come off drugs completely or have moved uninterruptedly in that direction. In 22 patients whose weaning is complete, the drug-free time averages 2.5 years. Weaning is now being done more slowly than at the beginning of the trial be- 


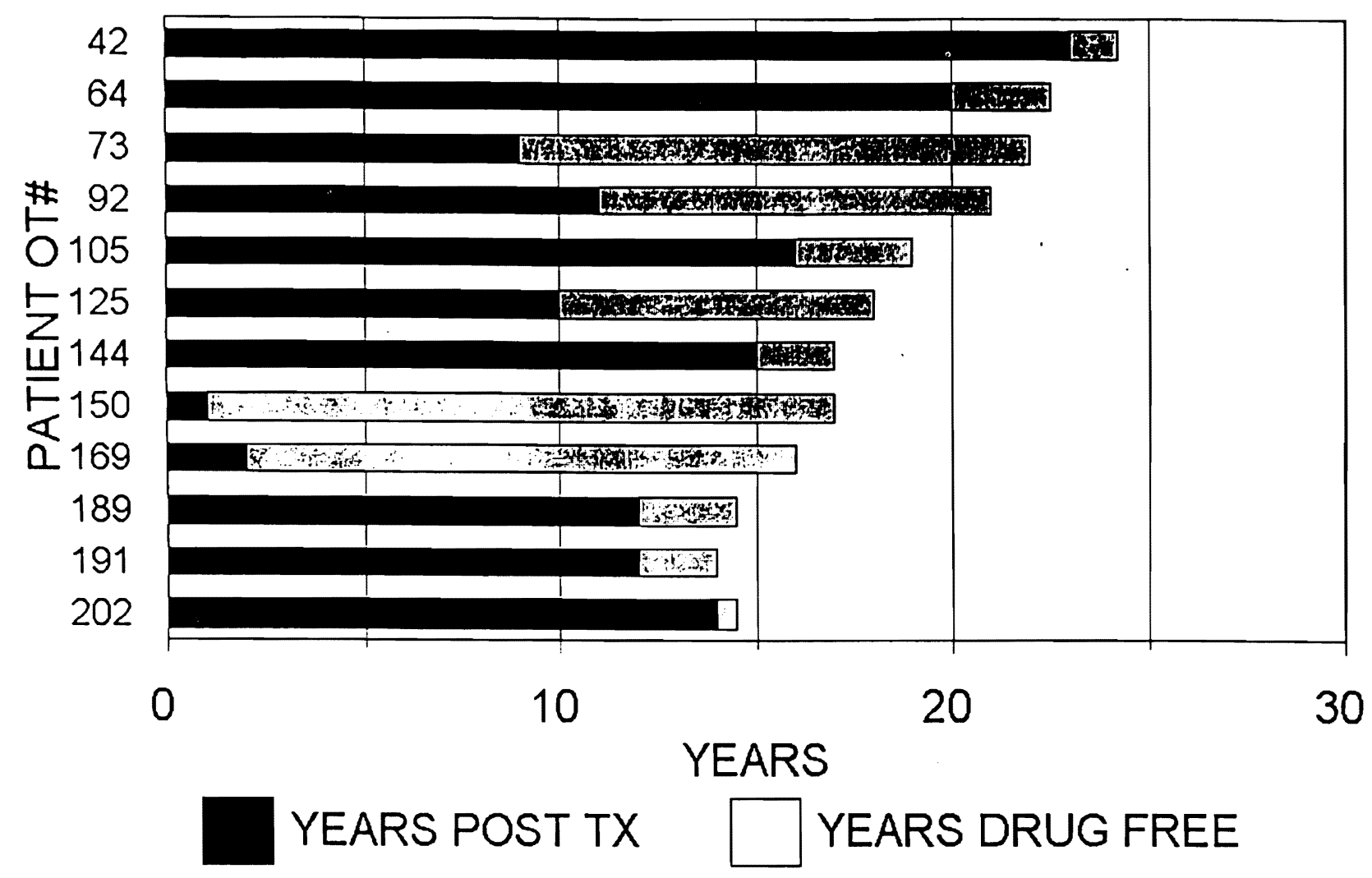

Figure 35-7 Time on (black) and off (gray) of immunosuppressive therapy of 12 long-term surviving liver transplant recipients having no drug treatment in October 1995 . Patients 150 and 169 stopped their medication less than 2 years after transplantation because of noncompliance. The other 10 were weaned because of complications of chronic immunosuppression. These 12 parients represent $28 \%$ of the 42 in our total experience who have continuously born hepatic allografts for 15 to $25-5 / 6$ years.

cause of a $30 \%$ incidence of rejection (see Fig. 35-8). It was evident that most of the 80 liver recipients had been at a level of immunosuppression higher than they needed.

The foregoing trial did not include cases in which immunosuppression was stopped because of life-threatening infections. Ten pediatric liver recipients whose drugs were discontinued permanently as early as 6 months after transplantation because of Epstein-Barr virus (EBV), associated B-cell lymphomas, human immunodeficiency virus (HIV), or heparitis $C$ virus are listed in Table 35-1..$^{.2}$ After an average drug-free period of more than 4 years, eight $(80 \%)$ of thesc 10 patients remain drug free and healthy, including 5 of the 6 patients whose EBV-associated $B$ cell lymphomas (also called postransplant lymphoproliferative disorders (PTLDs|) melted after drugs were stopped. The demonstration that thesc tumors respond to immunomodulation has been the most reproducible example of cancer immunosurveillance ever reported clinically."

It is more dangerous to attempt weaning after kidney transplantation, and we rarely recommend this. However, five of our longest-surviving living related kidncy recipients (the first five listed in T:able 35-2) have been off of all immunosuppression for 2 (1) 30 years. The first and third parienes, who had double HI A haploidencical donors, were noncompliant. However, the other three of the first five were HLA mismatched. They and the more recently treated patients 6,7 , and 8 had at least four of the serious complications of immunosuppression listed in the footnote. Only patient 8 (whose transplantation was done in 1987) had rejection with weaning. This was prompty diagnosed and easily reversed.

\section{Rejection after drug discontinuance}

The benefits of weaning from immunosuppressive therapy for organ recipients are obvious. However, it is equally important to recognize that there was a $30 \%$ overall risk for rejection in the prospective liver trial. Successful weaning was achieved consistently only in patients who were weaned from an azathioprine-prednisone regimen or from monotherapy with tacrolimus." When weaning failed, rejection was diagnosed 1 to 29 months after the beginning of weaning (see Fig. 35-8). Rejection was classed histopathologically as minimal to mild in 20 of 24 patients and moderate or severe in the other four.

Restoration of the previous bascline immunosuppression was the only adjustment required in most cases, but the four patients with moderate or severe rejection required rescue treatment with tacrolimus; one patient who required rescue treatment became jaundiced with a peak bilirubin of $12 \mathrm{mg} \%$. 


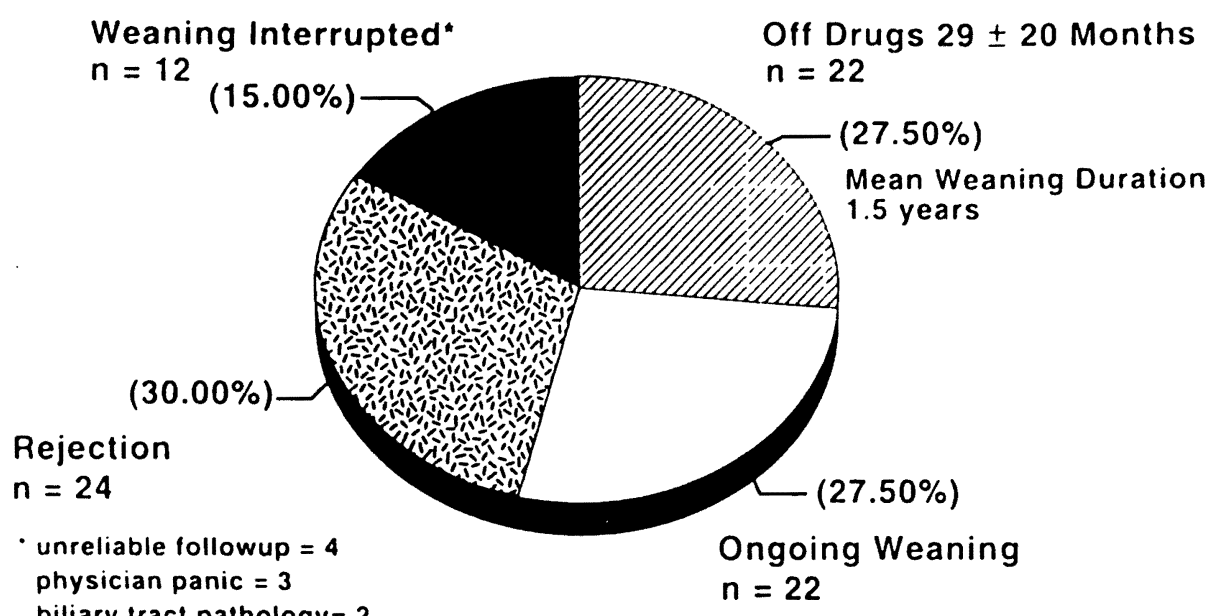

biliary tract pathology $=2$

$\mathrm{PBC}$ recurrence $=1$

renal failure $=1$

steatohepatitis $=1$
Figure 35-8 Summary of the first 80 liver recipients in a weaning trial at the University of Pittsburgh Medical Cinter. Note that more than half have been completely off of drugs or are on an interruped schedule of drug reduction. The rate of weaning has been slowed compared with the original protocol because of a $30 \%$ incidence of rejection. There have been no patients or graft losses. Weaning is incerrupted if noncompliance is detected or in the presence of intrinsic liver disease, including the reemergence of auroimmunc disorders.
Although no patients or grafts were lost in our trial, Sandborn et $\mathrm{al}^{65}$ encountered rejection in 6 of 12 patients being rapidly weaned from cyclosporine-based triple drug therapy only 3 years after transplantation; two of the six died. It would be foolhardy to ignore such a warning.

\section{Bone marrow transplantation}

After the discovery that successful whole organ transplantation was associared with spontaneous chimerism, it was realized that the perceived schism between the bone marrow and whole organ transplantation fields reflected entrenched differences in treatment strategy (Fig. 35-9). The mutually censoring immunologic limbs were left intact with organ transplantation, whereas the recipient limb was deliberarely removed (cytoablation) in preparation for bone marrow grafting procedures. Although it had long been assumed that the entire recipient immune system had been eliminated with successful bone marrow transplantation (see Fig. 35-1, B), a trace population of recipient leukocytes has been detected with sensitive techniques in the blood of almost all such patients. ${ }^{57.114}$ These bone marrow recipients were in fact mirror images of those successfully bearing whole organ allografts, the difference being that their own rather than donor leukocytes constitured the trace population. Under both circumstances, other such findings as the appearance of vero and suppressor cells, enhancing antibodies, and changes in cyrokine profile could be construed as by-products of and accessory to the seminal event of the mutual cell engagement (see Fig. 35-1, $C$ and $D$ ).

\section{ORGAN PRESERVATION}

\section{Procurement}

The breakthroughs of the early 1960s that made transplantation clinically practical were so unexpected that almost no formal preparation had been made to preserve the transplanted organs. Cardiac surgeons had used hyporhermia for open-hearr
Table 35-1 Outcome of Therapy Cessation in Pediatric Transplant Recipients with Infections*

\begin{tabular}{lccc}
\hline & PTLD & HIV & HCV \\
\hline$n$ & 6 & 2 & 2 \\
Time drugs stopped & Median 1 year & $6,7 \mathrm{yr}$ & $0.5 .2 \mathrm{yr}$ \\
$\quad$ after transplantation & $(0.8$ to 8 yrs.) & & \\
Survival & $5 / 6$ & $1 / 2$ & $2 / 2$ \\
Time drug free (yrs) & 4.1 & 6.1 & 4.2 \\
\hline
\end{tabular}

-A follow-up done until October 1995 of a series reported to the American Sociery of Transplant Surgeons in May 1993 (64).

HCV-Hepatic C virus; HIV_Human immunodeficiency virus: PTLDPostransplant lymphoproliferative disorders.

operations from 1950 onward and knew that ischemic damage below the level of aortic cross-clamping could be reduced by cooling the subdiaphagmatic organs." In an early report, Lillehei et al ${ }^{39}$ immersed intestines in iced saline before autotransplantation. In Boston, Sicular and Moore ${ }^{69}$ reported greatly slowed enzyme degradation in cold slices of liver.

Despite this awareness, kidneys from identical twins were routinely transplanted with no protection from warm ischemia during organ transfer. Until 1963, the only attempt to cool kidney allografts was by the potentially dangerous practice used by cardiac surgeons of immersing the living volunteer donor in a bathtub of ice water (total body hypothermia). ${ }^{79}$ This cumbersome mechod of cooling was quickly replaced by infusion of chilled solutions into the renal artery after donor nephrectomy, ${ }^{73}$ exploiting a principle of core (transvascular) cooling that had been standardized several years earlier for experimental liver transplantation. ${ }^{86}$

Core cooling in situ, which is currently the first critical step in the preservation of all cadaveric whole organs, is done with variations of the rechnique described in 1963 by Marchioro et $\mathrm{al}^{42}$ and was used clinically long before the acceptance of brain deach criteria which now pernits in situ cooling to be undertaken $^{75}$ (Fig. 35-10). Ackerman and Snell' ${ }^{2}$ and Merkel et al ${ }^{48}$ popularized in situ cooling of cadaveric kidneys with simple in- 
Table 35-2 Weaning of Immunosuppression in Long-Term Living Related Kidney Transplantation

\begin{tabular}{lcclc}
\hline PATIENT & YEARS AFTER TREATMENT & HAPLOTYPE MISMATCH & INDICATION FOR WEANING & YEARS OFF DRUGS \\
\hline $1 \mathrm{kp}$ & 33 & 0 & $\mathrm{nc}$ & 30 \\
$2 \mathrm{sin} \dagger$ & 32 & 1 & comp & 15 \\
$3 \mathrm{int}$ & 32 & 0 & $\mathrm{nc}$ & 29 \\
$4 \mathrm{jw} \dagger$ & 32 & 2 & comp & 3 \\
$5 \mathrm{ds} \dagger$ & 33 & 1 & comp & 2 \\
$6 \mathrm{ln}$ & 29 & 1 & comp & weaning \\
$7 \mathrm{ss}$ & 17 & 1 & comp & 1.5 \\
$8 \mathrm{jk}$ & 8 & 1 & comp & rejection (3 months) \\
\hline
\end{tabular}

C.rearinine $1.0 \rightarrow 3.4 \rightarrow 1.2 \mathrm{mg} \%$ (after rerurn to CyA/Pred)

tChildren at the time of transplantation.

Comp-Complications of skin cancer, warts, infection. hypertension, obesing, orthopedic problems: nc-Noncompliant.

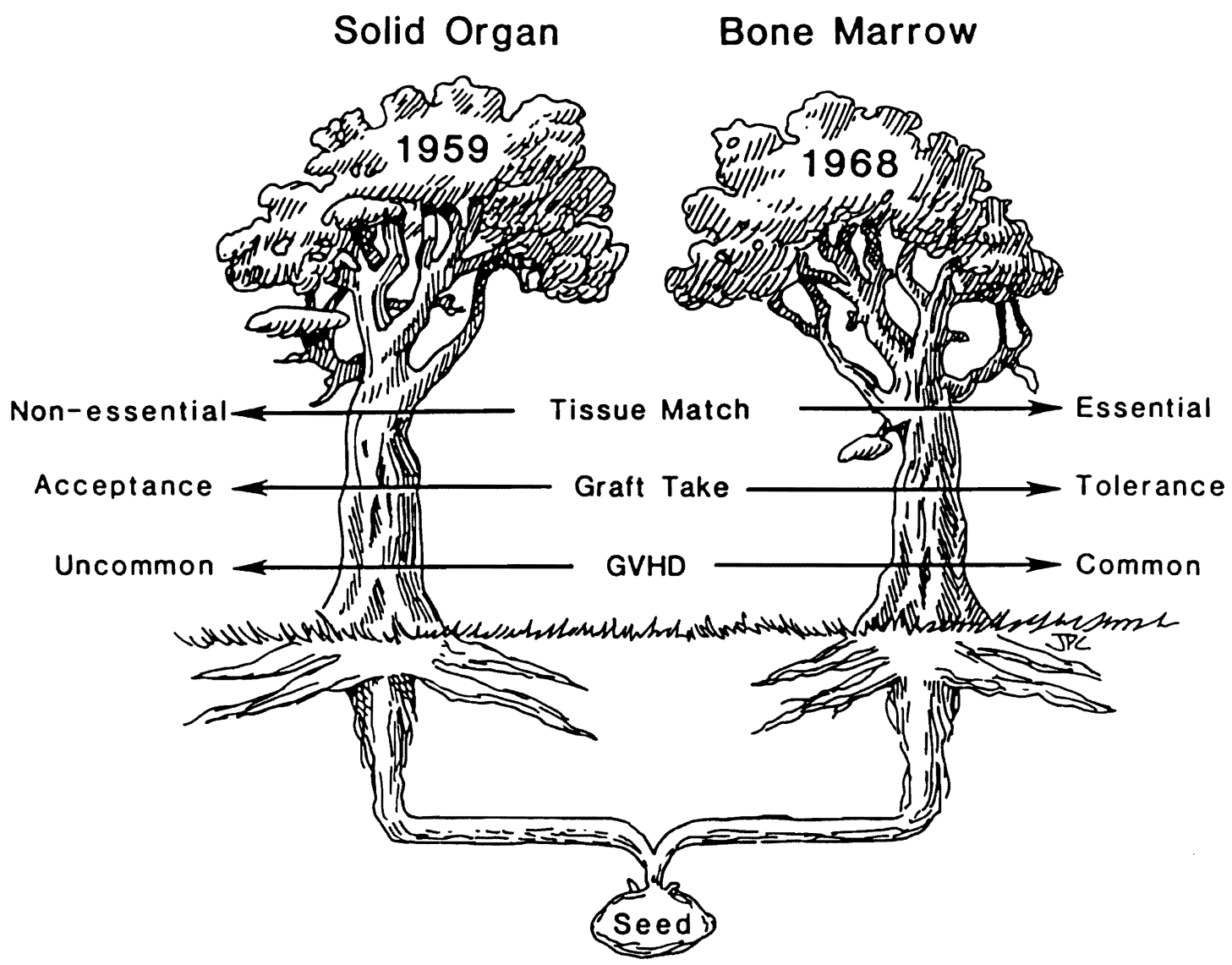

(Medawar)

Figure 35-9 The growth as separate disciplines of bone marrow (right) and whole organ transplantation (lefi) from the seed planted by Peter Medawar during World War II. It was recognized in 1992 that these seemingly disparate disciplines were mirror images caused by different treatment strategies. GVHD-Graft-versus-host disease.

fusion of cold clectrolyte solutions into the donor femoral artery or distal aorta. Procurement techniques were eventually perfected and allowed removal of all thoracic and abdominal organs, including the liver, without jeopardizing any of the individual organs (Fig. 35-11). ${ }^{\text {Ms }}$ Modifications of this flexible procedure have been made for unstable donors and even for donors whose hearts have stopped beating." During the 5 years berween 1980 and 1985, such techniques had become interchangeable in all parts of the world, setting the stage for reliable organ sharing. After the chilled organs are removed, subsequent preservation is possible with prototype strategies: simple refrigeration or continuous perfusion (see below). 


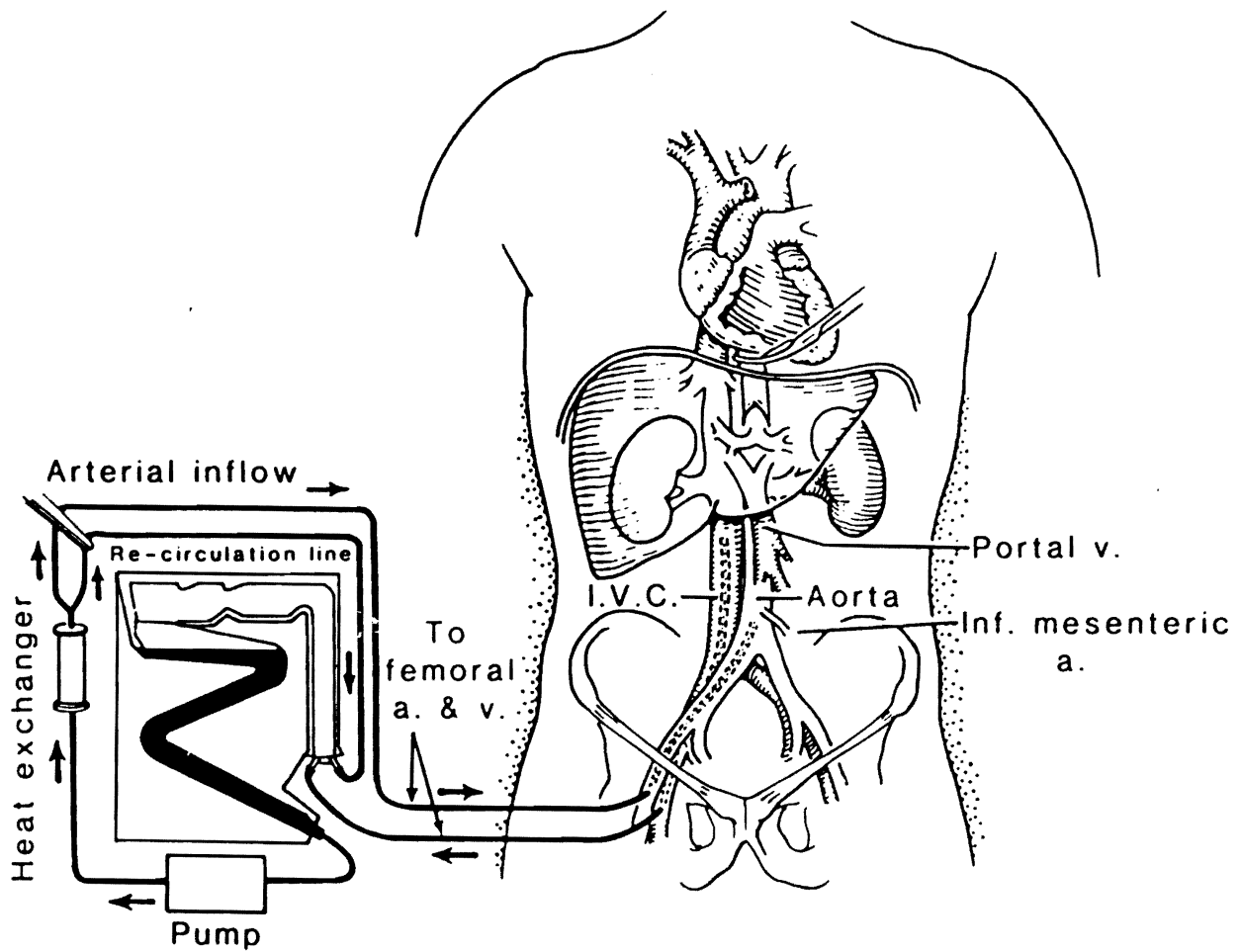

Figure 35-10 lïst technique of in situ cooling by extracorporcal hypothermic perfusion. The catheters were inserted into the aorta and vena civa by way of the femoral vessels as soon as possible after death. Temperature control was provided with a heat exchanger. Cross-clamping of the thoracic aorta limited perfusion to the lower part of the body. This method of cadaveric organ procurement was used from 1962 to 1969 , before the acceptance of brain death criteria. The preliminary stages of this approach provided the basis for subsequent in situ infusion techniques. (From Starzl TE: Experience in renal transplantation. In The role of cadaveric donors in homotransplantation, Philadelphia, 1964, WB Saunders.)

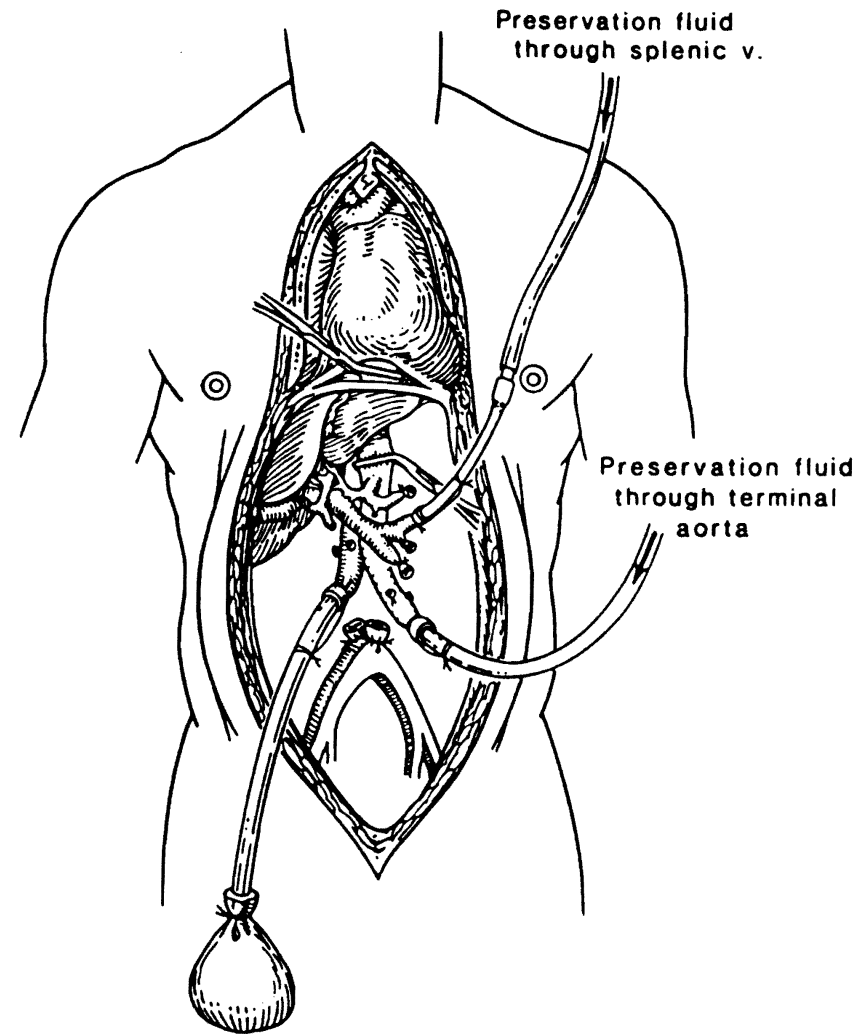

Figure 35-11 Principle of in situ cooling used for multiple organ procurement. With limited preliminary dissection of the aorta and of the great splanchnic veins (in this case the splenic vein), cold infusates can be used to chill organs in situ. In this case, rlie kidneys and liver were being removed. Note the aorcic cross-clamp above the celiac axis. (From Starzl TE er al: A tlexible procedure for mulciple cadaveric organ procurement, Surg Gynecol Obstet 158:22.3. 1984. Modified with permission.)

\section{Exfended Preservation}

\section{Continuous vascular perfusion}

In the first clinical application of continuous vascular perfusion, Marchioro et $\mathrm{al}^{42}$ used a conventional heart-lung machine and heat exchanger to continuously perfuse and cool all major organs (see Fig. 35-10). Efforts to continuously perfuse isolated organs proved to be more difficult. For renal allografts, Ackerman and Barnard' used a normothermic perfusate primed with blood and oxygenated within a hyperbaric oxygen chamber. The perfusate was directed into the renal artery. Brettschneider et al ${ }^{15}$ modified the apparatus and were able to preserve canine livers for 2 days, an unprecedented feat at the time. When Belzer et al ${ }^{10}$ eliminated the hemoglobin and hyperbaric chamber components, their asanguinous hyporhermic perfusion technique was immediately accepted for clinical renal transplantation but then slowly abandoned in most centers when it was learned that the quality of 2-day preservation was not markedly better than that of simpler and cheaper infusion and slush methods (see below). However, refinement of perfusion rechniques may someday permit true organ banking.

\section{Static preservation}

With these "slush techniques," special solutions, such as that described by Collins et al, ${ }^{20}$ or plasmalike solutions ${ }^{\left(x_{0}\right.}$ were instilled into the renal vascular system of kidneys or the vascular system of orher organs after their prelininary chilling and separation. The original Collins solution, or modifications of it were used for nearly 2 decades before they were replaced with the University of Wisconsin (UW) solution that was developed by the team of Folkert Belzer. Although it was first used for the liver. ${ }^{11.15 .1019}$ the UW solution provides superior preservation of 
kidneys 13.56 .111 and other organs. The UW preservation permired longer and safer preservation of kidneys ( 2 days) and livcrs (1 day), a higher rate of grafi survival, and a lower rate of primary nonfunction. With the UW solution, mational organ sharing was made economical and practical.

\section{TISSUE TYPING}

\section{Antigen Matching}

The first prospective antigen matching trials were begun in 1964 by Terasaki ${ }^{114}$ in collaboration with the University of Colorado kidney transplantation team. Although the value of this serologic technology was demonstrable when the kidney donor was a highly comparible family member (the perfect match), ${ }^{93}$ lesser degrees of matching correlated poorly with renal transplantation ourcome." The reason for this paradox were inexplicable until the discovery of recipient chimerism. Ironically, the belief that matching should be a prime determinant of success resulted in its use as an overriding factor for the allocation of cadaver kidneys in the United States.

The propriety of this kidney allocation policy has been repeatedly challenged on ethical as well as scientific grounds for a quarter of a century. Those in favor of its perperuation cite multicenter case compilations in the United States and Europe showing a small gain in allograft survival with histocompatible kidneys, whereas many of the individual contributing centers see no such trend in their own experience. ${ }^{27.43 .63 .100}$ In a compelling recent study, Terasaki et al ${ }^{102}$ reported that early survival and the subsequent half-life of kidneys from randomly matched living unrelated donors was identical to that of parent-offspring (one haplorype matched) grafts.

In addition to this hammerblow to matching, Gjertson, Cecka, and Terasaki ${ }^{30}$ have noted that tacrolimus-based immunosuppression improved cadaver kidney graft survival for more than any degree of matching, including perfect comparibility. With tacrolimus, the projected half-life of cadaver kidneys was twice that achievable with any previously available immunosuppressive regimen, including those based on cyclosporine (14 versus 7 years). These findings were consistent with those in single-center ${ }^{108}$ and multicenter liver transplantation trials. ${ }^{2(1 . \times 2.113}$ The inescapable conclusion is that more effecrive immunosuppressive therapy rather than refinements in tissuc matching and organ sharing will be the primary method of improving the results of whole organ transplantation.

\section{Cross Matching}

\section{Allotransplantation}

Nonc of the immunosuppressive measures available today can prevent immediate destruction of kidneys and other kinds of organ grafts in what has been called hyperacute rejection. This complication was first seen with the transplantation of kidneys from $A B($ )-incomparible donors when they were placed in re-

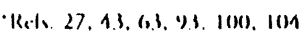

cipients with antidonor isoagglutinins. ${ }^{71}$ After the description by Terasaki, Marchioro, and Starzl ${ }^{103}$ of hyperacute kidney rejection by a recipient with antidonor lymphocytotoxic antibodies, Kissmeyer-Nielsen et al, ${ }^{37}$ and others ${ }^{87.107 .116}$ confirmed the association of hyperacute rejection with these antigraft antibodies. Although hyperacute rejection can usually be avoided with the lymphocytoroxic crossmatch originally recommended by Terasaki, Marchioro, and Starzl, ${ }^{103}$ the precise pathogenesis of such rejection remains poorly understood more than 25 years after its recognition as an innate (primitive) immune reaction caused by complement activation and inflammatory mediators. $^{78.87}$ Understanding and preventing this reaction is believed to be the key to successful xenotransplantation. ${ }^{96}$

\section{Xenotransplantation}

When organs are transplanted from a significantly disparate species, the first immunologic hurdle is that of preformed xenospecific antibodies and complement activation that quickly devascularize the graft by the same mechanisms as in $\mathrm{ABO}$ incompatible and presensitized allograft recipients. ${ }^{96}$ Although liver allografts and xenografts are resistant to such humoral (hyperacure) rejection, ${ }^{\text {96 }}$ human liver xenotransplantation using chimpanzee donors ${ }^{76}$ was unsuccessful three times between 1966 and 1973 with deaths after 0,9 , and 14 days. ${ }^{77}$ Two additional hepatic xenotransplantations were attempted in June 1992 and January 1993 with the phylogenetically more distant baboon donor. The recipients survived for 70 and 26 days. ${ }^{83.96}$ The grafts did not function normally, but neither antibody nor cellmediated rejection could be definitively indicted as responsible.

Nevertheless, there was indirect evidence that there had been a storm of inflammatory mediators, triggered by preformed xenospecific antibodies (principally IgM) and complement activation. The failures were similar to those that had occurred after clinical chimpanzee ${ }^{61}$ and baboon renal transplantation ${ }^{88}$ a third of a century ago and the more recent Baby Fae heart transplantation.' A new generation of complement inhibitors ${ }^{3}$ or the much-publicized creation of transgenic animal donors whose organs contain transfected human complement regulatory genes ${ }^{45.115}$ may provide the missing piece in the treatment puzzle. Norwithstanding such hopes, the practical objective of clinical xenotransplantation remains elusive, even with the use of closely related species.

\section{REFERENCES}

1. Ackerman JR, Barnard $C N$ : A report on the successful storage of kidncys, Br J Surg 53:525, 1966.

2. Ackcrman JR, Sincll MR: Cadaveric renal transplantation, Br J Urol 4():515, 19)3.

3. Anderson C.B. Sicard C;A, litheredge l:Li: Pretreatment of renal allograti recipients with azathioprinc and donor-specific blood products, Surgery $92: 315,1982$.

4. Bach I: Hirschhorn K: L.ymphexyec interaction: a potential histocompantibility esst in vitro. Science 143:813, 1964.

5. Bach I:H: Bonc-marrow transplantation in a parient with the Wiskot1-Aldrich syndrome, Isenced 2:1,364, 1968.

6. Bailcy I. ct al: Balxoon to hum:un cardiac xenotransplantation in a ncentatc, JAMA 254:3321, 1985. 
7. Bain B, Vas MR, Iowenstein 1.: The development of large immature mononuclear cells in mixed leukncyte cultures, Blond 23:108, 1964.

8. Barber WH et al: Long-term results of a controlled prospective study with transfusion of donor specific bone marrow in 57 cadaveric renal allograft recipients, Transplantation 51:70, 1991.

9. Barnard CN: What we have lcarned about heart transplants. J Thorac Cardiovase Surg 56:457, 1968.

10. Belzer FO, Ashby BS. Dunphy JE: 24-hour and 72 hour preservation of canine kidncys, Lancet 2:536, 1967.

11. Belzer FO, Southard JH: Principles of solid-organ prescrvation by cold storage, Transplantation 45:673, 1988.

12. Billingham R, Brent L: A simple method for inducing tolerance of skin homografts in micc, Trans Bull 4:67, 1957.

13. Billingham RE, Brent L. Medawar PB: "Activcly acquircd tolerance" of foreign cells, Nature 172:603, 1953.

14. Billingham R, Brent L, Medawar P: Quantitative studies on tissue transplantation immunity. III. Actively acquired colerance, Philos Trans R Soc Lond (Biol) 239:357, 1956.

15. Brettschneider $\mathrm{L}$ et al: The use of combined preservation techniques for extended storage of orthotopic liver homografts, Surg Gynecol Obstet 126:263, 1968.

16. Burnet FM: The new approach to immunology, $N$ Engl / Med 264:24, 1961.

17. Calne RY: The rejection of renal homografts: inhibition in dogs by 6-mercaptopurine, Lancet 1:417, 1960.

18. Calne RY: Inhibition of the rejection of renal homografts in dogs with purine analogues, Transplant Bull 28:445, 1961.

19. Calne RY et al: Cyclosporin A initially as the only immunosuppressant in 34 recipients of cadaveric organs: 32 kidneys, 2 pancreases, and 2 livers, Lancet 2:1033, 1979.

20. Collins GM, Bravo-Shugarman M, Terasaki PI: Kidney preservation for transportation: initial perfusion and 30 hours ice storage, Lancet 2:1219-24, 1969.

21. Dausset J: The HLA adventure. In Terasaki PI, editor: History of HLA: ten recollections, Los Angeles, 1990. UCLA Tissue Typing Laboratory.

22. Demetris AJ et al: Hematolymphoid cell trafficking, microchimerism, and GVHD reacrions after liver, bone marrow, and heart transplantation, Transplant Proc 25:3337, 1993.

23. Derom $F$ et al: Ten-month survival after lung homorransplancation in man, J Thorac Cardiovasc Surg 61:835, 1971.

24. Doherty PC: The keys to cell-mediated immunity, JAMA 274:1067-68, 1995

25. Elion GB, Bieber S. Hitchings GH: The fare of 6-mercapropurine in mice, Ann NY Acad Sci 60:297, 1955.

26. The European FK 506 Multicentre Liver Study Group: Randomised trial comparing tacrolimus (FK 506) and cyclosporin in prevention of liver allograft rejection. Lancet 344:423. 1994.

27. Ferguson $R$, for the Transplant Information Share Group (TISG): A multicenter experience with sequential ALG/cyclosperine therapy in renal transplantation. Clin Transpl 2:285. 1988.

28. Fontes $P$ et al: Augmentation with bone marrow of donor leukocyte migration for kidney, liver, heart, and pancreas islet transplantation, Lancet 344:151, 1994.

29. Garti RA et al: Immunological reconstitution of sex-linked lymphopenic immunological deficiency. Lancer 2:1366. 1968.

30. Gjertson DW. Cecka JM. Terasaki PI: The relarive effects of FK 506 and cyclosporine on short- and long-term kidney graft survival. Transplantation 60:1384, 1995.

31. Goulet $O$ et al: Successful small bowel transplantation in an infant. Transplantation 53:940, 1992.

32. Hamburger $J$ et al: Renal homotransplantation in man after ratdiation of the recipient. Ain / Med 32:854, 1962.

33. Hoffman B er al: Use of UW solution for kidncy transplantation, Transplantarion 46:338, 1988.
34. Hume DM et al: The homotransplantation of kidncys and of fetal liver and spleen after total body irradiation. Ann Surg 152:354, 1960.

35. Kalayoglu $M$ et al: lixtended preservation of the liver for clinical transplantation, lancet 1:617, 1988.

36. Kelly $W[$ ) et al: Allotransplantation of the pancreas and duodenum along with the kidncy in diabetic nephropathy, Surgery $61: 827,1967$.

37. Kissmeycr-Niclson F" et al: Hyperacutc rejection of kidncy allografts, associated with precxisting humoral ancibodics against donor cells, Lancet 2:622, 1966.

38. Kuss $\mathrm{R}$ et al: Homologous human kidney transplantation. Experience with six patients, P'ostgrad Med J 38:528, 1962.

39. Lillehei RC, Goott B, Miller FA: The physiological response of the small bowel of the dog to ischemia including prolonged in vitro preservation of the bowel with successful replacement and survival, Ann Surg 150:543, 1959.

40. Main JM, Prehn RT: Successful skin homografts after the administration of high dosage $\mathrm{X}$ radiation and homologous bone marrow, J Natl Cancer Inst 15:1023, 1955.

41. Mannick JA et al: A functioning kidney homotransplant in the dog, Surgery 46:821, 1959.

42. Marchioro TL et al: Extracorporeal perfusion for obtaining postmorten homografts, Surgery 54:900, 1963.

43. Matas AJ, Sutherland DER, Najarian JS: The impact of HLA matching on graft survival, Transplantation 54:568, 1992.

44. Mathe $G$ et al: Haematopoietic chimera in man after allogenic (homologous) bone marrow transplantation, $\mathrm{Br}$ Med J 1633. 1963.

45. McCurry $\mathrm{K}$ et al: Human complement regulatory proteins protect swine to primate cardiac xenografts from humoral injury, Nature Med 1:423, 1995.

46. Medawar PB: The behavior and fate of skin autografts and skin homografts in rabbits, J Anat 78:176, 1944.

47. Meeker $W$ et al: Prolongation of skin homograft survival in rabbits by 6-mercaptopurine, Proc Soc Exp Biol Med 102:459. 1959.

48. Merkel FK, Jonasson O, Bergan JJ: Procurement of cadaver donor organs: evisceration technique. Transplant Proc 4:585. 1972.

49. Merrill JP et al: Successful homotransplantation of the human kidney between identical twins, JAMA 160:277, 1956.

50. Merrill JP et al: Successful homotransplantation of the kidney berween non-identical twins, $N$ Engl J Med 262:1251. 1960.

51. Monaco AP. Clark AW, Brown RW: Active enhancenent of a human cadaver renal allograft with ALS and donor bone marrow: case report of an initial attempt, Surgery 79:384, 1976.

52. Murase $\mathrm{N}$ et al: Variable chimerism, graft versus host disease. and colerance after different kinds of cell and whole organ transplantation from Lewis to Brown-Norway rats. Transplantation 60:158, 1995.

53. Murray JE et al: Kidney transplantation in modified recipients. Ann Surg 156:337. 1962.

54. Murray JE et al: Prolonged survival of human-kidney homografts by immunosuppressive drug theripy. $N$ Engl J Med 268:1.315. 1963.

55. Owens TC. Prevedel AE. Swan H: Prolonged experimental occlusion of thoracic aorta during hyporhermia. Arch Surg 70:97. 1955.

56. Ploeg RJ et al: Successful 72-hour cold storage of dog kidneys with UIV solution. Transplantation 46:191. 1988.

57. Preepiorka D et al: Use of a probe to repeat sequence of the $Y$ chromosome for decection of host cells in peripheral blood of bone marrow tr:usplant recipients. Hematopathology 95:201. 19)1.

58. Qian S er al: Murine liver allograft transplantation: rolerance and donor cell chinerism. Heparology 19:916. 1994. 
59. Ramos HC: or al: Weaning of immunosuppression in long term liver transplant recipients. Transplantation 59:212, 1995.

(6). Rapaport F"T et al: Induction of unresponsiveness to major transplantable organs in adult mammals, Ann Surg 190:461, 1979.

61. Recomtsma K et al: Renal heterotransplantation in man, Ann Surg $160: 384,1964$.

62. Reyes $f$ et al: The frequent achictement of a drug free state after orthotopic liver cransplantacion, Transplant Proc 25:3315. $19) 3$.

6.3. Salvaticra (). Jr: Optimal use of organs for transplantation. $N$ Engl J Med 318:1329, 1988.

64. Salvatierra O. Jr et al: Deliberatc donor-specific blood transfusions prior to living related renal transplantation. A new approach, Ann Surg 192:54.3. 1980.

65. Sandborn W] et al: Cyclosporine withdrawal for nephrotoxicity in liver transplant recipients does not result in sustained improvement in kidney function and causes cellular and ductopenic rejection, Hepatology 19:925, 1944.

66. Schalm SW: A simple and clinicilly applicable merhod for the preservation of a liver homografi. Unpublished data, University of Leyden. Holland, 1968 (thesis).

67. Schwarrz R, Dameshek W: Drug-induced immunological tolerance, Nature 183:1682, 1959.

68. Schwartz R, Dameshek W: The effects of 6-mercaptopurine on homograft reactions, J Clin Invest 39:952, 1960.

69. Sicular A. Moore FD: The postmortem survival of tissues, J Surg Res 1:16, 1961.

70. Simonsen $M$ : The impact on the developing embryo and newborn animal of adult homologous cells, Acta Path Microbiol Scand 40:480, 1957.

71. Snell GD: The homograft reaction, Ann Rev Microbiol 11:439, 1957.

72. Sollinger $H W$ et al: Donor-specific transfusions in unrelated and related HLA-mismatched donor-recipient combinations, Transplantation 38:612, 1984.

73. Starzl TE: Donor nephrectomy. In Experience in renal transplantation, Philadelphia, 1964, WB Saunders.

74. Starzl TE: Patterns of permissible donor-recipient tissue transfer in relation to $A B O$ blood groups. In Experience in renal transplantation. Philadelphia, 1964, WB Saunders.

75. Starzl TE: The role of cadaveric donors in homotransplantation. In Experience in renal transplantation, Philadelphia, 1964, WB Saunders.

76. Starzl TE: Orthotopic heterotransplantation. In Experience in hepatic transplantation. Philadelphia, 1969. WB Saunders.

77. Starnl TE: Baboon renal and chimpanzee liver heterotransplantation. In Hardy MA, editor: Xenograft 25, Amsterdam \& NY Excerpta-Medical, 1989, Elsevier Science.

78. Starzl TE et al: Clotting changes, including disseminated intravascular coagulation, during rapid renal-homograft rejection, $N$ Engl J Med 283:383, 1970.

79. Starr. TE et al: Renal transplantation in identical twins, Arch Surg 865:600, 1963.

80. Staral TE et al: Cell migration, chimerism, and graft acceptance, lancer 339:1579, 1992.

81. Staral TF et al: Cell migration and chimerism after whole organ transplantation: the basis of graft acceptance, Hepatology 17:1127. 19) 3 .

82. Starral T\% a al: Randomized trialomania? The multicenter liver transplant crials. Isncet 346:1346, 1995.

83. Staral T1: at al: Babren-to-human liver transplantation, Lancet $341: 65,1093$.

84. Staral Tl: cial: ()rehotopic homotransplantation of the human liver, Ann Sury 168:392, 1968.

85. Starrl 11: ex al: A flexible procedure for multiple cadaveric organ procurement, Surg Gynecol Obstet 158:223. 1984.
86. Starzl TE et al: Reconstructive problems in canine liver homotransplantation with special reference to the postoperative role of hepatic venous flow, Surg Ciynecol Obstet 111:733, 1960.

87. Starzl TE et al: Shwartzman reaction after human renal transplantation, $N$ Engl J Med 278:642, 1968.

88. Starl TE et al: Renal heterotransplantation from baboon to man: experience with 6 cases, Transplantation 2:752, 1964.

89. Starzl TE et al: The use of heterologous antilymphoid agents in canine renal and liver homotransplantation and in human renal homotransplantation, Surg Gynecol Obstet 124:301, 1967.

90. Starzl TE, Marchioro TL, Waddell WR: The reversal of rejection in human renal homografts with subsequent development of homograft tolerance, Surg Gynecol Obstet 117:385, 1963.

91. Starzl TE et al: An improved technique for multiple organ harvesting, Surg Gynecol Obstet 165:343, 1987.

92. Starzl TE et al: Reversibility of lymphomas and lymphoproliferative lesions developing under cyclosporin-steroid therapy, Lancet 1:583, 1984.

93. Starzl TE et al: Long-term survival after renal transplantation in humans: with special reference to histocompatibility matching, thymectomy, homograft glomerulonephritis, heterologous ALG, and recipient malignancy, Ann Surg 172:437, 1970.

94. Starzl TE et al: Transplantation of multiple abdominal viscera, JAMA 261:1449, 1989.

95. Starzl TE et al: FK 506 for human liver, kidney and pancreas transplantation, Lancet 2:1000, 1989.

96. Starzl TE et al: The biologic basis of and strategies for clinical xenotransplantation, Immunol Rev 141:213, 1994.

97. Steinman RM: The dendritic cell system and its role in immunogenicity, Annu Rev Immunol 9:271, 1991.

98. Steinman RM, Cohn ZA: Identification of a novel cell type in peripheral lymphoid organs of mice. I. Morphology, quantitation, tissue distribution, J Exp Med 137:1142, 1973.

99. Steinmuller D: Immunization with skin isografts taken from tolerant mice, Science 158:127, 1967.

100. Tatemoto $S$ et al: Survival of nationally shared HLA-matched kidney transplants from cadaveric donors, $N$ Engl J Med 327: 834, 1992.

101. Terasaki PI, editor: History of HLA: ten recollections, Los Angeles, 1990, UCLA Tissue Typing Laboratory.

102. Terasaki PI et al: High survival rates of kidney transplants from spousal and living unrelated donors, $N$ Engl J Med 333:333, 1995.

103. Terasaki PI, Marchioro TL, Starl TE: Sero-typing of human lymphocyte antigens: Preliminary trials on long-term kidney homograft survivors. In Russel PS, Winn HJ, Amos DB, editors: Histocompatibility testing, Washington, DC, 1965, National Academy of Science-National Research Council.

104. Terasaki PI et al: Serotyping for homotransplantation. VII. Selection of kidney donors for thirty-two recipients, $A n n N Y$ Acad Sci 129:500, 1966.

105. Thomas ED: Allogeneic marrow grafiing-A scory of man and dog. In Terasaki PI, cditor: History of iransplantation: thirty-five recollections, Los Angeles, 1991, UCLA Tissuc Typing Laboratory.

106. Thomson AW, Starzl TE, editors: Immunosuppressive drugs: developments in anti-rejection therapy, London, 1994, Edward Arnold Publishing.

107. Ting A: The lymphocytotoxic crossmatch test in clinical renal transplantation, Transplantation 35:403. 1983.

108. Todo $S$ et al: Single center experience with primary orthotopic liver transplantation under $1: \mathrm{K} 506$ immunosuppression, Ann Surg 220:297, 1994.

109. Fodo $S$ et al: lixtended preservation of human liver grafts with UW solution, JAMA 261:711, 1989.

110. Trentin J): Induced colerance and "homologous disease" in $X$-irradiated mice protected with homologous bone marrow, I'roc Soc lixp Biol Med 96:13\%, 1957. 
111. Ueda $Y$ et al: The UW solution for canine kidney preservation: its specific effect on renal hemodynamics and microvasculature, Transplantation 48:913, 1989.

112. Unanue ER: The concept of antigen processing and prescutation. JAMA 274:1071, 1995.

113. The U.S. Multicenter I:K 506 Liver Study (iroup: A comparison of tacrolimus (FK 506 ) and cyclosporine for immunosuppression in liver transplantation, $N$ lingl J Med 331:1110, 1994.

114. Wessman $M$ et al: Detection of residual host cells after bonc marrow transplantation using non-isotopic in situ hybridization and karyotype analysis, Bone Marrow Transplant 11:279, 1993.

115. Cozzi $\mathrm{E}$ et al: Effect of transgenic expression of human decay- accelerating factor on the inhibition of hyperacute rejection of pig organs. In Cooper DKC; et al, editors: Xenotransplentation. The eransplantation of organs and tissues between species. ed 2. Springer-Verlag. 1997. Heildelberg.

116. Williams ( $M M$ et al: Studies in hyperacute and chronic renal homograft rejection in man, Surgery 62:204, 1967.

117. Kinkernagel RM: The MHC;-restricted $\%$-cell recognition, JAMA 274:1069, 1995.

118. \%ukoski CF, Lee HM, Hume DM: The prolongation of functional survival of caninc renal homografts by (6-mercaptopurine, Surg forum 11:470, 1960. 